\title{
Acute Effects of Mimosine Purified from Leucaena leucocephala on Male Reproductive System of Adult Mice
}

\author{
Efectos Agudos de la Mimosina Purificada de Leucaena leucocephala \\ en el Sistema Reproductor Masculino de Ratones Adultos
}

Pipatpong Kanla ${ }^{1,2}$; Jaturon Burawat ${ }^{1,2}$; Supatcharee Arun ${ }^{1,2}$;

Tarinee Sawatpanich $^{1,2}$; Amnart Chaichun ${ }^{1,2}$ \& Sitthichai Iamsaard ${ }^{1,2,3}$

KANLA, P.; BURAWAT, J.; ARUN, S.; SAWATPANICH, T.; CHAICHUN, A. \& IAMSAARD, S. Acute effects of mimosine purified from Leucaena leucocephala on male reproductive system of adult mice. Int. J. Morphol., 36(2):507-512, 2018.

SUMMARY. This study attempted to examine the acute effect of purified minosine extracted from Leucaena leucocephala on male reproductive system. Adults male mice were divided into 4 groups $(n=8)$; control and 3 experimental groups treated with purified mimosine at different doses of 15,30 , and $60 \mathrm{mg} / \mathrm{KgBW}$, respectively for 7 consecutive days. The morphological features and weights of body and reproductive organs including testis, epididymis plus vas deferens, and seminal vesicle were compared among groups. In addition, epididymal sperm concentration and the changes of histopathology of testicular tissues in all groups were observed. The results showed that mimosine in all doses did not affect mice body weights. However, all doses of mimosine could significantly reduce the absolute and relative weights of testis and seminal vesicle but not of epididymis plus vas deferens. Significantly, mimosine at doses of 30 , and $60 \mathrm{mg} / \mathrm{KgBw}$ could decrease sperm concentration. Moreover, the seminiferous atrophy and degeneration were obviously found in mimosine treated mice as compared to the control. In conclusion, consumption of Leucaena leucocephala edible parts containing mimosine could damage male reproductive organs which may cause acute male subfertility or infertility.

KEY WORDS: Mimosine; Leucaena leucocephala; Testis; Seminal vesicle; Mice.

\section{INTRODUCTION}

The Leucaena leucocephala (Lamk.) de Wit (LL) has many properties such as used for human food, forage, firewood, soil erosion prevention, and high nutritive resources for cattle (Hong et al., 2003; Meena Devi et al., 2013). This plant's extracts have been documented to contain antioxidant activities (Benjakul et al., 2013; Hassan et al., 2014; Burawat et al., 2016). However, it is very well known that this plant is toxic to cattle and poultry animals because it caused the retardation of growth, sub and infertility and death (Wayman et al., 1970; Hammond, 1995; Anderson et al., 2001). Recently, LL leave extract is shown to have adverse effect on male reproductive system of adult rats (Burawat et al.). Possibly, these toxic effects may result from mimosine action documented as a major toxic content in LL extract (Adeneye, 1991; Chanchay \& Poosaran, 2009).

Mimosine has been reported to have inhibitory activities of many cancers, cell divisions, cell proliferations and differentiations (Wang et al., 1995; Hughes \& Cook,
1996; Krude, 1999). In addition, mimosine is responsible for herbicidal, insecticide, and nematicide activities (Tawata, 1990; Nguyen \& Tawata, 2015). Indeed, mimosine also can arrest the cell cycle progression to inhibit cell proliferation of many cancer cells (Chung et al., 2012; Park et al., 2012; Bottini-Luzardo et al., 2015; Fallon, 2015; Nguyen \& Tawata; Kacar et al., 2017). To provide the basic information to caution people about subfertility or infertility effects from acute consumption of the LL parts containing natural mimosine; therefore, this study attempted to investigate the acute effects of purified mimosine extracted from Leucaenaleucocephala on reproductive system in male mice.

\section{MATERIAL AND METHOD}

Standard mimosine preparation. Purified L-Mimosine powders were purchased from Sigma-Aldrich, Lot\#

\footnotetext{
${ }^{1}$ Department of Anatomy, Faculty of Medicine, Khon Kaen University, 123 Mittaparb Road, Maung, District, Khon Kaen, 40002, Thailand.

${ }^{2}$ Reproductive Biomedicine Research Unit, Faculty of Medicine, Khon Kaen University, 123 Mittaparb Road, Maung, District, Khon Kaen, 40002 , Thailand.

${ }^{3}$ Center for Research and Development of Herbal Health Product, Faculty of Pharmaceutical Sciences, Mittaparb Road, Khon Kaen, 40002, Thailand.
} 
077K $7007 \mathrm{~V}$, USA. To prepare a mimosine stock solution, the standard mimosine powder $(1 \mathrm{~g})$ was mixed with $0.1 \mathrm{~N}$ $\mathrm{HCl}$ adjusted for the $\mathrm{pH}$ with $\mathrm{NaOH}(\mathrm{pH} 7)$.

Animals and treatments. ICR male mice (6-8 weeks) were purchased from the Animal Laboratory Unit, Faculty of Medicine, Khon Kaen University, Thailand. Then, mice were housed in plastic cages with wood chip bedding under a $12 \mathrm{~h}$ light/dark cycle at room temperature. This study was duly approved by the Animal Ethics Committee of KKU, based on the Ethics of Animal Experimentation of the National Research Council of Thailand (ref. No.0514.1.12.2/ 93). For treatment regime, male mice were randomly divided into 4 groups $(\mathrm{n}=8)$; in control group, mice were injected vehicle solution $(0.1 \mathrm{~N} \mathrm{HCl}, \mathrm{pH} 7)$ and for 3 experimental groups (mimosine 15, 30, and 60), animals were injected (i.p.) with mimosine at 15,30 , and $60 \mathrm{mg} / \mathrm{KgBW}$, respectively for 7 consecutive days. Mice were daily weighed throughout the experimental period. At the end of experiment, all mice were euthanized and sacrificed to collect and testis, epididymis plus vas deferens, and seminal vesicles.

Organ weight analysis and gross morphology. The testis, epididymis plus vas deferens, and seminal vesicles from control and experimental animals were collected. The fat pads surrounding such organs were gentle removed before weighing as absolute organ weight. Then, all reproductive organs were calculated as individual relative organ weights using a formulation of one hundred multiplied by the absolute weight of reproductive organ and divided with mice body weight ( $g$ of organ/100gBw). After weighing the reproductive organs, the representative organs of control and mimosine treated groups were grossly observed for their sizes and morphology. All organs of both groups were captured by digital camera (Nikon Coolpix S2600, Japan) to be compared for morphological changes.

Sperm concentration assay. Sperm fluid was squeezed from left caudal epididymis plus vas deferens and dipped into 1 $\mathrm{ml}$ of phosphate buffered saline (PBS, $37^{\circ} \mathrm{C}, \mathrm{pH}$ 7.4). Then, diluted sperm fluid was centrifuged at $5000 \mathrm{rpm}, 25^{\circ} \mathrm{C}$, for 2 min to wash sperm and followed by sperm pellet resuspension with $1 \mathrm{ml}$ of PBS. To analyze the sperm number, the sperm suspension was diluted (1:20) before placing on Neubauer counting chamber to systemically count and calculate them as sperm concentration (¥106) in triplicate examinations (Iamsaard et al., 2013).

Histopathological examination. The testes were fixed in $10 \%$ phosphate buffered formalin ( $\mathrm{pH} \mathrm{7.4)}$ for $48 \mathrm{~h}$. Then, the fixed tissues were routinely processed for light microscope examination using automatic tissue processing at the Pathology Department, Faculty of Medicine, Khon
Kaen University. Subsequently, the paraffinized-tissue blocks were sectioned at 5-7 $\mu \mathrm{m}$ thickness and stained by hematoxylin and eosin. The stained-tissue slides were dehydrated, cleared, and mounted before observation under light microscope. The histological sections were captured by Nikon light ECLIPSE E200 microscope equipped with a DXM1200 digital camera to observe the histopathological changes of seminiferous tubules and interstitial tissues between the mimosine and control groups.

Statistical analysis. All data are expressed as mean \pm standard deviation (S.D.). The one way analysis of variance (ANOVA) was performed to examine the significant differences among sets of data using SPSS statistics 19.0 software (IBM SPSS Statistics). $\mathrm{P}<0.05$ was considered for significant difference.

\section{RESULTS}

Effect of mimosine on body weight. After injection of purified mimosine for 7 consecutive days, the results showed that the interval body weight of animals treated with mimosine $(15,30$, or $60 \mathrm{mg} / \mathrm{KgBw})$ were not significantly different from that of control mice (Fig. 1). Notably, the ranges of averaged body weight in control and different mimosine-treated groups were approximately 30-35 grams as shown in Figure 1.

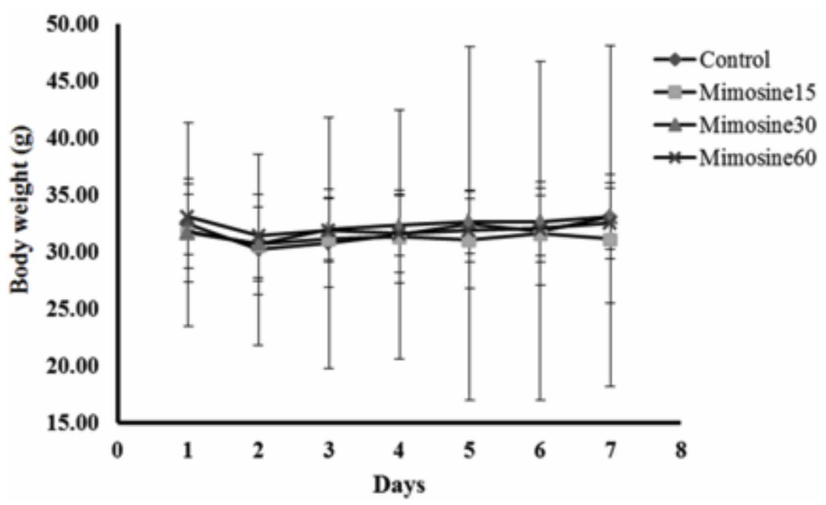

Fig. 1. Comparisons of daily body weights in 7 consecutive days of control and experimental groups (treated with 15, 30, and 60 $\mathrm{mg} / \mathrm{KgBw}$, respectively). Each data point represented as means \pm S.D. $(\mathrm{n}=8)$

Effects of mimosine on reproductive morphology. The comparisons of gross morphological aspects of testis, epididymis plus vas deferens, and seminal vesicle among control, 15, 30, and $60 \mathrm{mg} / \mathrm{kgBw}$ of mimosine treated groups were demonstrated in Figure 2 (A, B, and C, respectively). 
The results showed that testis and epididymis plus vas deferens in mimosine treated mice in 3 different doses were not obviously seen to be different from each other as compared to those organs of control group (Fig. 2 A, B). In contrast, the gross morphology of seminal vesicle of mice treated with only a dose of $60 \mathrm{mg} / \mathrm{KgBw}$ was obviously smaller

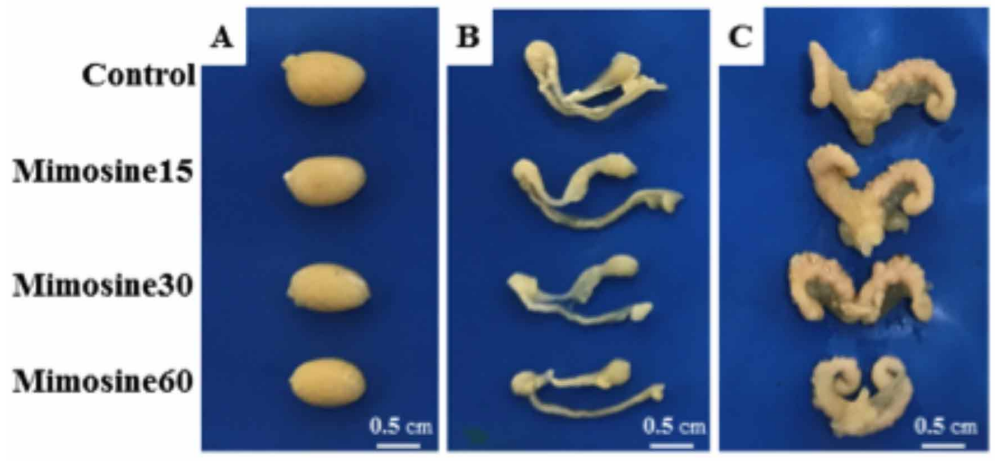

Fig. 2. Representative gross structures of testis (A), epididymis plus vas deferens (B), and seminal vesicles (C) of control and mimosine-treated mice at doses of 15,30 , or $60 \mathrm{mg} / \mathrm{KgBw}$, respectively.

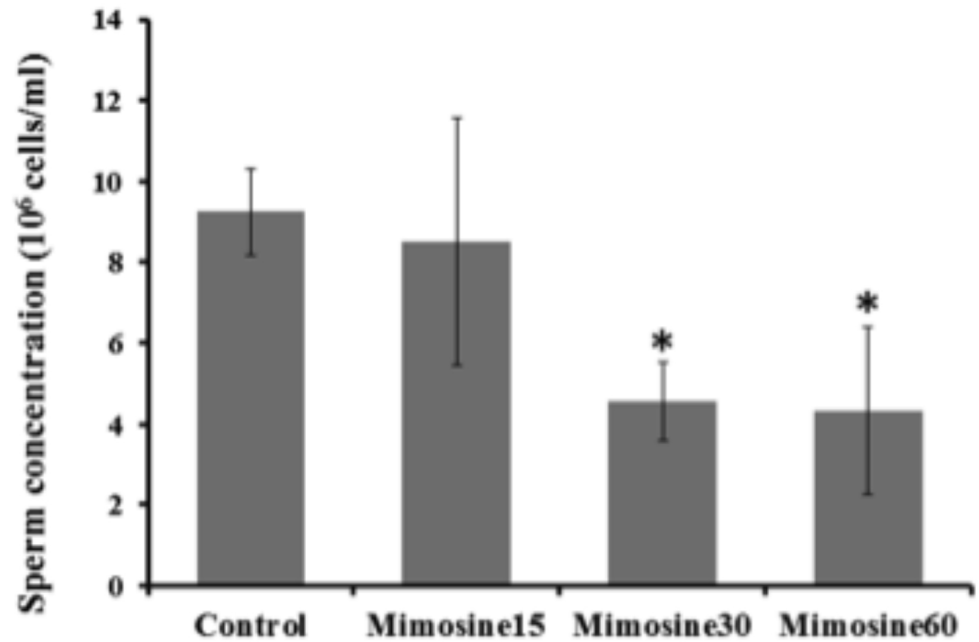

Fig. 3. Sperm concentration of control and mimosine-treated mice $(15,30$, or $60 \mathrm{mg} / \mathrm{KgBw})$. Each data point represented as means \pm S.D. $(\mathrm{n}=8)$. * Significant difference $(\mathrm{p}<0.05)$ compared to the control. than that of control and two lower doses of mimosine (15 and $30 \mathrm{mg} / \mathrm{KgBw}$ ) shown in Figure $2 \mathrm{C}$.

Effects of mimosine on male reproductive organ weights. The weights of testis, epididymis plus vas deferens, and seminal vesicle of control and mimosine treated groups were quantified as absolute and relative organ weights shown in Table I. The absolute weight of testis in all mimosine treated groups were significantly decreased as compared to the control $(\mathrm{p}<0.05)$, but only mimosine groups of 30 and $60 \mathrm{mg} /$ $\mathrm{KgBw}$ had significantly reductions of relative organ weight (Table I). Corroborated with gross structure results (Fig. 2), all weights of epididymis plus vas deferens among control and mimosine treated groups were not significantly different from each other ( $p>0.05)$. Interestingly, both absolute and relative weights of seminal vesicles in all three mimosine treated groups were significantly decreased $(\mathrm{p}<0.05)$ as compared to that of control mice.

Effects of mimosine on sperm concentration. To examine the acute effect of purified mimosine on sperm production, the caudal epididymal sperm were counted and calculated as sperm concentration (Fig. 3). The results revealed that mimosine at doses of 30 and $60 \mathrm{mg} / \mathrm{KgBw}$ could significantly reduce $(\mathrm{p}<0.05)$ sperm concentration as compared to the control or low dose mimosine group (15 mg/KgBw) as shown in Figure 3.

Acute effects of mimosine on testicular histology. The representative testicular histology, stained by basic hematoxyline and eosin dyes, of control and mimosine groups are shown in

Table I. Absolute and relative weights of testis, epididymis plus vas deferens, and seminal vesicles in control and experimental mice treated with 15,30 , and $60 \mathrm{mg} / \mathrm{KgBw}$ of purified mimosine.

\begin{tabular}{|c|c|c|c|c|}
\hline Reproductive organ weights & Control & Mimosine15 & Mimosine30 & Mimosine60 \\
\hline \multicolumn{5}{|l|}{ Testis } \\
\hline Absolute weight (g) & $0.2938 \pm 0.01$ & $0.2499 \pm 0.03 *$ & $0.2584 \pm 0.01 *$ & $0.2670 \pm 0.01 *$ \\
\hline Relative weight (g) & $0.8024 \pm 0.12$ & $0.8024 \pm 0.12$ & $0.8488 \pm 0.11 *$ & $0.8957 \pm 0.03 *$ \\
\hline \multicolumn{5}{|l|}{ Epididymis plus vas deferens } \\
\hline Absolute weight (g) & $0.0767 \pm 0.01$ & $0.0588 \pm 0.01$ & $0.0614 \pm 0.01$ & $0.0635 \pm 0.01$ \\
\hline Relative weight (g) & $0.1929 \pm 0.02$ & $0.1864 \pm 0.02$ & $0.2024 \pm 0.04$ & $0.1996 \pm 0.05$ \\
\hline \multicolumn{5}{|l|}{ S eminal vesicles } \\
\hline Absolute weight (g) & $0.3956 \pm 0.09$ & $0.2149 \pm 0.08 *$ & $0.1921 \pm 0.08 *$ & $0.2043 \pm 0.08 *$ \\
\hline Relative weight (g) & $0.9322 \pm 0.21$ & $0.6945 \pm 0.27 *$ & $0.3997 \pm 0.36^{*}$ & $0.6374 \pm 0.27 *$ \\
\hline
\end{tabular}



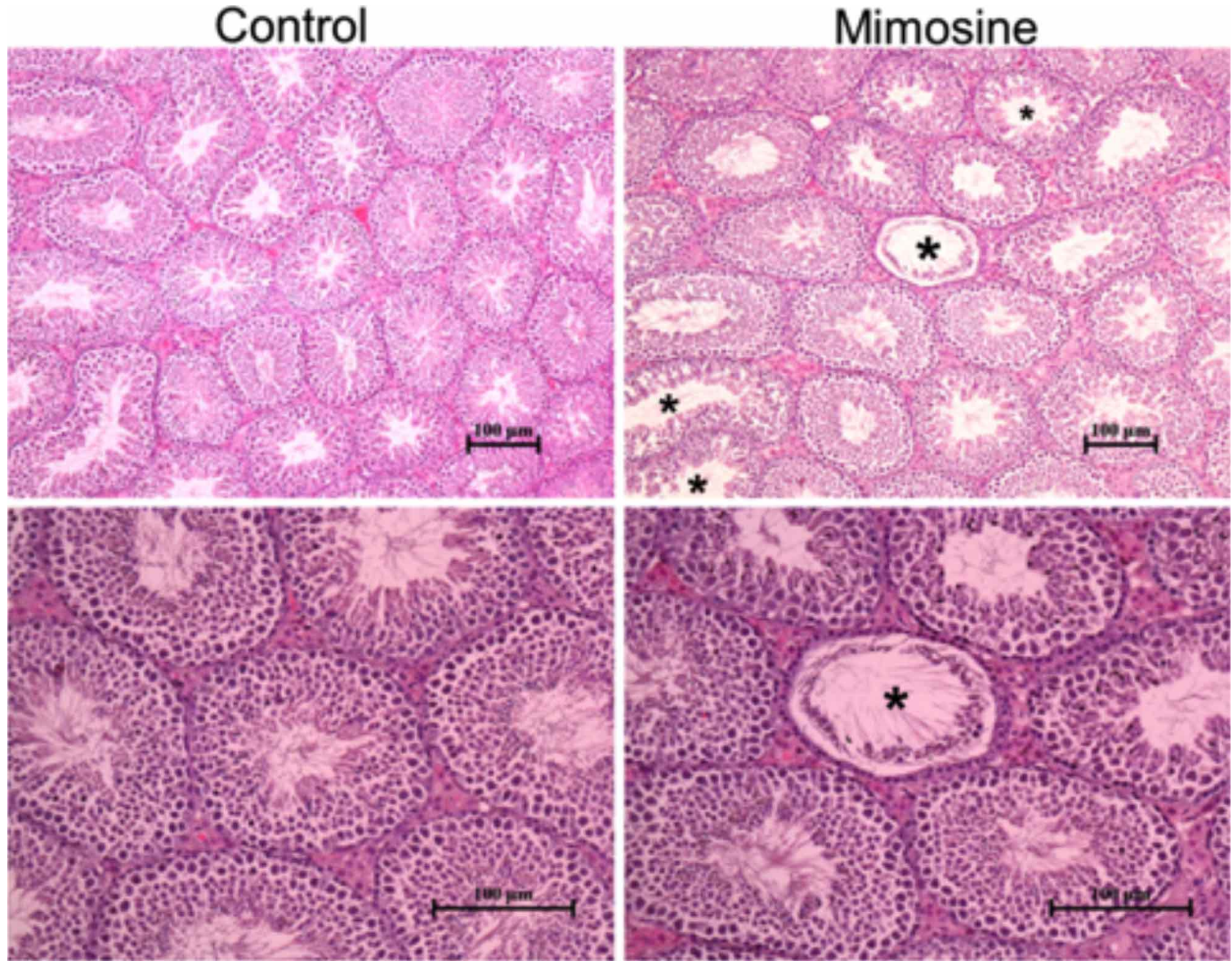

Fig. 4. Showing histopathology of representative testicular tissue of control (left panel) and mimosine-treated mice (right panel). Atrophic and germ cell degenerative seminiferous tubule (asterisks).

Figure 4. The results showed that seminiferous tubules and interstitial tissues of control mice have normal arrangement histology (Fig. 4, left panel). In contrast, it was found that mimosine in all doses could damage only seminiferous tubule approximately $10-15 \%$ of normal tissues (Fig. 4, right panel). In histopathology of mimosine treated groups, it was observed that only slight atrophy and germ cell degeneration within tubule were notably found as compared to the control (Fig. 4). Herein, other typical testicular histopathology such as increased interstitial tissue space and dilated blood vessels were not found in all mimosine treated groups (Fig. 4).

\section{DISCUSSION}

It is very well known that all parts of Leucaena leucocephala (LL) tree especially leaves and seeds contain a cellular toxin, namely mimosine, which is proven to have inhibitory activities of many cancers, cell divisions, cell proliferations and differentiations (Wang et al.; Hughes \& Cook; Krude). The levels of mimosine content in LL depends on many factors such as locations, ages of plant, soil types, seasons, and extraction methods (Ghosh \& Bandyopadhyay, 2007). Mimosine level extracted from LL grown in India was $3.33 \%$ dry weight (Mathews \& Vittal Rai, 1985) whereas of plant grown in Australia was $45 \mathrm{~g} / \mathrm{kg}$ (or $4.5 \%$ ) dry weight (Tangendjaja et al., 1986). Additionally, the mimosine level in LL fresh leaves harvested in Malaysia examined by using High Performance Liquid Chromatography was $1.6 \%$ wet weight (Zayed et al., 2014). By colorimetric determination, mimosine level in LL leaves grown in North, Thailand was $4.4 \%$ dry weight of total proteins (Chanchay \& Poosaran). Our research group has investigated the level of mimosine content in aqueous crude extract of LL shoot tips plus young leaves cultured in Northeastern, Thailand by using Thin Layer Chromatography with method validation for the first time and we found that 
its mimosine level was $17.35 \%$ dry crude extract (Burawat, 2017). Previous study has demonstrated that LL crude extract could damage male reproductive system (Burawat et al.). Confirmed by specific action of mimosine, the present study has demonstrated that purified minosine extracted from LL could directly affect reproductive organs of male mice with acute treatment. Particularly, it was found that mimosine damages testicular tissue (Fig. 4) which may affect the spermatogenesis resulting in significant decrease of epididymal sperm concentration (Fig. 3). We hypothesize that mimosine may have a major function as anti-cell proliferation of male germ cells since previous reports have demonstrated in other system about theinhibitory activities of many cancer cells, cell divisions, cell proliferations and differentiations, herbicidal, insecticide, and nematicide activities (Tawada, 1990; Wang et al.; Hughes \& Cook; Krude; Chung et al.; Park et al.; Bottini-Luzardo et al.; Fallon; Nguyen \& Tawata). Similar to others, the testicular histopathology, such as atrophic and germ cell degenerating seminiferous tubules, damaged by mimosine in this study was also comparable to other anti-cellular division drug demonstrated previously (Iamsaard et al., 2014; Sukhorum et al., 2016; Sukhorum \& Iamsaard, 2017; Iamsaard et al., 2017a,b; Sampannang et al., 2017). In conclusion, the acute consumption of LL containing high mimosine levels must be avoided to protect the reproductive impairment in men. In parallel, further study about reversible infertility effect of mimosine should be investigated to apply this substance to be a male contraceptive.

\section{ACKNOWLEDGEMENTS}

This study was granted by Faculty of Medicine, Khon Kaen University, Thailand (Grant Number IN 60126) to PK and SI.

KANLA, P.; BURAWAT, J., ARUN, S., SAWATPANICH, T.; CHAICHUN, A. \& IAMSAARD, S. Efectos agudos de la mimosina purificada de Leucaena leucocephala en el sistema reproductor masculino de ratones adultos. Int. J. Morphol., 36(2):507-512, 2018.

RESUMEN: Este estudio intentó examinar el efecto agudo de la mimosina purificada extraída de Leucaena leucocephala en el sistema reproductivo masculino. Se dividieron ratones machos adultos en 4 grupos $(n=8)$ : un grupo control y tres grupos experimentales tratados con mimosina purificada a diferentes dosis de 15,30 y $60 \mathrm{mg} / \mathrm{Kg}$ por peso, respectivamente, durante 7 días consecutivos. Se compararon entre los grupos, las características morfológicas y el peso corporal, los órganos reproductivos, incluyendo los testículos, el epidídimo más conducto deferente y vesícula seminal. Además, se observó la concentración de espermatozoides epididimarios y los cambios de la histopatología de los tejidos testiculares en todos los grupos. Los resultados mostraron que la mimosina no afectó los pesos corporales de los ratones. Sin embargo, todas las dosis de mimosina podrían reducir significativamente los pesos absolutos y relativos de los testículos y las glándulas seminales, pero no así del epidídimo y los conductos deferentes. La mimosina en dosis de 30 y $60 \mathrm{mg} / \mathrm{Kg}$ por peso podría disminuir significativamente la concentración de esperma. Además, se observó la atrofia y degeneración seminífera en ratones tratados con mimosina en comparación con el grupo control. En conclusión, el consumo de partes comestibles de Leucaena leucocephala que contienen mimosina podría dañar los órganos reproductivos masculinos, lo que puede causar subfertilidad masculina aguda o infertilidad.

PALABRAS ClAVE: Mimosina; Leucaena leucocephala; Testículo; Glándulas seminales; Ratón.

\section{REFERENCES}

Adeneye, J. A. Mimosine content in various fractions of Leucaena leucocephala grown in western Nigeria. Anim. Feed Sci. Technol., 33(34):349-53, 1991.

Anderson, R. C.; Anderson, T. J.; Nisbet, D. J.; Kibbe, A. S.; Elrod, D. \& Wilkinson, G. Drought associated poisoning of cattle in South Texas by the high quality forage legume Leucaena leucocephala. Vet. Hum. Toxicol., 43(2):95-6, 2001.

Benjakul, S.; Kittiphattanabawon, P.; Shahidi, F. \& Maqsood, S. Antioxidant activity and inhibitory effects of lead (Leucaena leucocephala) seed extracts against lipid oxidation in model systems. Food Sci. Technol. Int., 19(4):365-76, 2013.

Bottini-Luzardo, M.; Aguilar-Perez, C.; Centurion-Castro, F.; SolorioSanchez, F.; Ayala-Burgos, A.; Montes-Perez, R.; Muñoz-Rodriguez, D. \& Ku-Vera, J. Ovarian activity and estrus behavior in early postpartum cows grazing Leucaena leucocephala in the tropics. Trop. Anim. Health Prod, 47(8):1481-6, 2015.

Burawat, J. Effects of Leucaena leucocephala (Lamk.) De Wit Shoot Tips Plus Young Leaves Aqueous Extract Containing Mimosine on Reproductive System of Adult Male Rats. Ph.D. Dissertation. Khon Kaen, Khon Kaen University, 2017.

Burawat, J.; Uabandit, N.; Sripanidkulchai, B.; Nualkaew, S. \& Iamsaard, S. Antioxidant capacity and acute testicular toxicity of Leucaena leucocephala aqueous shoot tips plus young leaves extracts. Int. J. Morphol., 34(2):514-21, 2016.

Chanchay, N. \& Poosaran, N. The reduction of mimosine and tannin contents in leaves of Leucaena leucocephala. Asian J. Food Agro-Industry, 2009:S137-44, 2009.

Chung, L. C.; Tsui, K. H.; Feng, T. H.; Lee, S. L.; Chang, P. L. \& Juang, H. H. L-Mimosine blocks cell proliferation via upregulation of B-cell translocation gene 2 and $\mathrm{N}$-myc downstream regulated gene 1 in prostate carcinoma cells. Am. J. Physiol. Cell Physiol., 302(4):C676-85, 2012.

Fallon, A. M. Effects of mimosine on Wolbachia in mosquito cells: cell cycle suppression reduces bacterial abundance. In Vitro Cell Dev. Biol. Anim., 51(9):958-63, 2015.

Ghosh, M. K. \& Bandyopadhyay, S. Mimosine toxicity-A problem of Leucaena feeding in ruminants. Asian J. Anim. Vet. Adv., 2:63-73, 2007.

Hammond, A. C. Leucaena toxicosis and its control in ruminants. J. Anim. Sci., 73(5):1487-92, 1995.

Hassan, R. A.; Tawfik, W. A. \& Abou-Setta, L. M. The flavonoid constitunts of Leucaena leucocephala. Growing in Egypt, and their biological 
activity. Afr. J. Tradit. Complement. Altern. Med., 11(1):67-72, 2014.

Hong, N. H.; Xuan, T. D.; Eiji, T.; Hiroyuki, T.; Mitsuhiro, M. \& Khanh, T. D. Screening for allelopathic potential of higher plants from Southeast Asia. Crop Prot., 22(6):829-36, 2003.

Hughes, T. A. \& Cook, P. R. Mimosine arrests the cell cycle after cells enter S-phase. Exp. Cell Res., 222(2):275-80, 1996.

Iamsaard, S.; Burawat, J.; Kanla, P.; Arun, S.; Sukhorum, W.; Sripanidkulchai, B.; Uabundit, N.; Wattathorn, J.; Hipkaeo, W.; Fongmoon, D. \& Kondo, H. Antioxidant activity and protective effect of Clitoria ternatea flower extract on testicular damage induced by ketoconazole in rats. J. Zhejiang Univ. Sci. B, 15(6):54855, 2014.

Iamsaard, S.; Prabsattroo, T.; Sukhorum, W.; Muchimapura, S.; Srisaard, P.; Uabundit, N.; Thukhammee, W. \& Wattanathorn, J. Anethum graveolens Linn. (dill) extract enhances the mounting frequency and level of testicular tyrosine protein phosphorylation in rats. $J$. Zhejiang Univ. Sci. B, 14(3):247-52, 2013.

Iamsaard, S.; Sukhorum, W.; Arun, S.; Phunchago, N.; Uabundit, N.; Boonruangsri, P. \& Namking, M. Valproic acid induces histologic changes and decreases androgen receptor levels of testis and epididymis in rats. Int. J. Reprod. Biomed. (Yazd.), 15(4):217-24, 2017a.

Iamsaard, S.; Sukhorum, W.; Sampannang, A. \& Sripanidkulchai, B. Protective effect of Momordica cochinchinensis (L.) spreng aril extract on essential testicular markers in rats induced with valproic acid. Int. J. Morphol., 35(3):992-9, 2017 b.

Krude, T. Mimosine arrests proliferating human cells before onset of DNA replication in a dose-dependent manner. Exp. Cell Res., 247(1):148-59, 1999.

Mathews, A. \& Vittal Rai, P. Mimosine content of Leucaena leucocephala and the sensitivity of rhizobium to mimosine. J. Plant Physiol., 117(4):377-82, 1985.

Meena Devi, V. N.; Ariharan, V. N. \& Nagendra Prasad, P. Nutritive value and potential uses of Leucaena leucopephala as biofuel - A mini review. Res. J. Pharm. Biol. Chem. Sci., 4(1):515-21, 2013.

Nguyen, B. C. \& Tawata, S. Mimosine Dipeptide Enantiomsers: Improved Inhibitors against Melanogenesis and Cyclooxygenase. Molecules, 20(8):14334-47, 2015.

Park, S. Y.; Im, J. S.; Park, S. R.; Kim, S. E.; Wang, H. J. \& Lee, J. K. Mimosine arrests the cell cycle prior to the onset of DNA replication by preventing the binding of human Ctf4/And-1 to chromatin via Hif-1a activation in HeLa cells. Cell Cycle, 11(4):761-6, 2012.

Sampannang, A.; Arun, S.; Sukhorum, W.; Burawat, J.; Nualkaew, S.; Maneenin, C.; Sripanidkulchai, B. \& Iamsaard, S. Antioxidant and hypoglycemic effects of Momordica cochinchinensis Spreng. (gac) aril extract on reproductive damages in streptozotocin (stz)-induced hyperglycemia mice. Int. J. Morphol., 35(2):667-75, 2017.

Sukhorum, W. \& Iamsaard, S. Changes in testicular function proteins and sperm acrosome status in rats treated with valproic acid. Reprod. Fertil. Dev., 29(8):1585-92, 2017.

Sukhorum, W.; Sampannang, A.; Sripanidkulchai, B. \& Iamsaard, S. Momordica cochinchinensis (L.) Spreng. aril extract prevents adverse reproductive parameters of male rats induced with valproic acid. Int. J. Morphol., 34(3):870-6, 2016.

Tangendjaja, B.; Lowry, J. B. \& Wills, R. B H. Changes in mimosine, phenol, protein and fibre content of Leucaena leucocephala leaf during growth and development. Aust. J. Exp. Agr., 26:315-37, 1986.

Tawata, S. Effective Reduction and Extraction of Mimosine from Leucaena and the Potential for Its Use as a Lead Compound of Herbicides. In: Casida, J. E. (Ed.). Pesticide and Alternatives. Amsterdam, Elsevier Science Publishers, 1990. pp.541-54.

Wang, Y.; Zhao, J.; Clapper, J.; Martin, L. D.; Du, C.; DeVore, E. R.; Harkins, K.; Dobbs, D. L. \& Benbow, R. M. Mimosine differentially inhibits DNA replication and cell cycle progression in somatic cells compared to embryonic cells of Xenopus laevis. Exp. Cell Res., 217(1):84-91, 1995.
Wayman, O.; Iwanaga, I. I. \& Hugh, W. I. Fetal resorption in swine caused by Leucaena leucocephala (Lam.) de Wit. in the diet. $J$. Anim. Sci., 30(4):583-8, 1970.

Zayed, M. Z.; Zaki, M. A.; Ahmad, F. B.; Ho, W. S. \& Pang, S. L. Comparison of mimosine content and nutritive values of Neolamarckia cadamba and Leucaena leucocephala with medicago sativa as forage quality index. Int. J. Sci. Technol. Res., 3(8):14650, 2014.

Corresponding author:

Dr. Sitthichai lamsaard

Department of Anatomy

Faculty of Medicine

Khon Kaen University

123 Mitrapap Road

Amphoe Muang, Khon Kaen 40002

THAILAND

Email: sittia@kku.ac.th

Received: 20-10-2017

Accepted: 06-02-2018 